\title{
PENGAJARAN KOSAKATA BAHASA INGGRIS DENGAN MEDIA REALIA DAN FLASH CARD
}

\author{
Widya, Tiarma Ika Yuliana, Yulia Sofiani
}

\author{
Program Studi Pendidikan Bahasa Inggris \\ Fakultas Bahasa dan Seni, Universitas Indraprasta PGRI \\ widya.center@gmail.com,tiarmaika@gmail.com,Oleel27@yahoo.com
}

\begin{abstract}
Abstrak
Kegiatan pengabdian kepada masyarakat ini bertujuan untuk memberikan pelatihan kepada wali murid tentang teknik pengajaran kosakata bahasa Inggris dengan media realia dan flash cards, sehingga wali murid bisa menerapkannya di rumah bersama anak-anak. Metode yang diterapkan dalam pengabdian ini adalah three period lesson yang dikembangkan oleh Edouard Seguin. Three period lesson ke dalam tiga tahap yaitu Naming Period (Introduction), Recognition and Association Period (Identification), Recall Period (Cognition). Hasil menunjukkan bahwa Penerapan pengajaran kosakata dengan media realia dan flashcards dengan menerapkan metode three period lesson dikatakan efektif dalam meningkatkan kemampuan penguasaan kosakata murid dan juga efektif untuk menumbuhkan minat belajar anak karena anak dimungkinkan untuk merasakan nuansa pembelajaran dan pengalaman baru yang lebih menyenangkan. Hal ini berampak positif terhadap peningkatan penguasaan kosakata anak.
\end{abstract}

Kata kunci: kosakata, realia, flash cards, three period lesson

\begin{abstract}
This community service activity aims to provide a training of teaching vocabulary by using realia and flash cards to parents so that they can apply them with children at home.The method applied in this devotion is the three period lesson developed by Edouard Seguin. Three period lessons is classified into three stages: Naming Period (Introduction), Recognition and Association Period (Identification), Recall Period (Cognition). The results show that the application of vocabulary teaching with realia and flashcards by applying the three period lessons methods is said to be effective in improving students' vocabulary mastery and is also effective to foster interest in children's learning as it is possible for children to feel the nuances of a new and an enjoyable learning process. This has a positive impact on improving vocabulary mastery of children.
\end{abstract}

Key words: Vocabularies, realia, flash cards, three period lesson

\section{PENDAHULUAN}

Kosakata atau perbendaharaan kata adalah jumlah seluruh kata dalam suatu bahasa, yang juga merupakan katakata yang dimiliki, diketahui, dan digunakan seseorang dalam berbicara, mendengar, membaca atau menulis. Kasihani (2007: 43) dalam bukunya yang berjudul English For Young Learners mengemukakan bahwa kosakata merupakan kumpulan kata yang dimiliki oleh suatu bahasa dan memberikan makna bila kita menggunakan bahasa tersebut. Penguasaan kosakata yang cukup, penting untuk mempelajari bahasa di tingkat yang lebih tinggi. Oleh karena itu pengajaran kosakata harus 
mendapat prioritas utama pada tahap awal pengajaran bahasa. Decarrio dalam Fauziati (2010: 61) menyatakan bahwa "Vocabulary learning is central to language acquisition, whether the language is first, second, or foreign". Dengan kata lain, keterampilan bahasa akan mudah dikuasai bila pembelajar menguasai kosakata terlebih dahulu.

Pembelajaran kosakata juga menjadi prioritas untuk diajarkan kepada siswa usia dini. Seperti dikatakan oleh Fauziati (2010: 91) bahwa" Children in primary or elementary school are at the concrete operational stage of cognitive development and classroom activities should create and offer opportunities to learners for learning." Usia tumbuh kembang anak adalah masa yang sangat efektif untuk memperkenalkannya pada kosakata baru. Namun, tentu saja strategi yang tepat akan sangat membantu anak dalam belajar.

Penguasaan kosakata yang baik dapat dicapai salah satunya dengan menggunakan metode dan teknik yang tepat dalam pembelajaran. Metode dan teknik konvensional memang cukup efektif untuk membantu anak untuk menguasai kosakata, namun terkadang metode dan teknik tersebut juga menimbulkan kebosanan pada anak karena kurang adanya variasi. Kebosanan tentu saja akan mempengaruhi motivasi anak dalam belajar. Karena itu dibutuhkan metode dan teknik yang lebih variatif sehingga anak berkesempatan untuk merasakan pengalaman baru yang lebih menyenangkan ketika belajar. Kesesuaian antara metode dan teknik pengajaran memiliki peran penting dalam mencapai suatu tujuan pengajaran yang diharapkan. Larsen-Freeman (2000: 1) mengatakan, "Language teaching method is a coherent set of links between actions and thoughts in language teaching. The actions are the techniques and the thoughts are the principles." Pernyataan tersebut menjelaskan bahwa metode pengajaran bahasa bukanlah sebatas cara pengajaran, akan tetapi adalah suatu kesatuan yang utuh antara pemikiran dan pelaksanaannya yang mengedepankan ketepatan antara teknik dan prinsip pengajaran bahasa sehingga tujuan pengajaran dapat tercapai dengan baik.

Penggunaan media adalah teknik yang cocok digunakan untuk mengajarkan bahasa baru kepada anak usia dini. Media realia dan flash card adalah dua diantara sekian banyak media yang dapat diaplikasikan dalam pengajaran kosakata. Realia merupakan benda nyata yang digunakan sebagai media pembelajaran di dalam kelas. Sebenarnya objek nyata yang sederhana pun dapat digunakan tidak hanya untuk pengajaran kosakata tetapi juga dapat dipakai untuk pengajaran tata bahasa dan pengembangan situasi. Menurut Nunan (1999: 98) "realia is object and teaching props from the world outside the classroom that are used for teaching and learning". Realia didefinisikan sebagai objek dan alat peraga dari dunia luar kelas yang digunakan untuk mengajar dan belajar. Realia dianggap sebagai benda nyata, yang digunakan untuk membantu dalam berlatih bahasa baru, sebagai cara untuk menyajikan contoh dari dunia nyata. Oleh karena itu, realia banyak digunakan dalam proses belajar mengajar sebagai alat bantu memperkenalkan subjek baru. Realia mampu memberikan arti nyata kepada hal-hal yang sebelumnya hanya digambarkan secara abstrak yaitu dengan kata-kata atau hanya visual. Bentuk realia sama dengan benda sebenarnya yang tidak mengalami perubahan sama sekali dan dapat digunakan untuk keperluan pembelajaran.

"Realia helps to make English language input as comprehensible as possible and to build "an associative bridge between the classroom and the world" (Bryan, 1997). Pelajar bisa 
langsung menghubungkan bahasa dengan objek yang disebutkan. Proses belajar mengajar akan sangat efektif dan menyenangkan dengan menggunakan media ini. Dan yang paling penting adalah murid tidak akan mudah melupakan aktifitas di dalam kelas.

Akan tetapi, kesulitan kadang timbul dalam menghadirkan realia secara utuh yang disebabkan oleh ukuran yang terlalu besar atau sulit ditemukan di lingkuangan sekitar. Oleh karena itu, beberapa modifikasi seringkali harus dilakukan. Untuk mengatasi kesulitan yang mungkin muncul dengan penggunaan media realia, seperti bila objek nyata tidak dapat langsung diperlihatkan kepada anak, pengajaran kosakata juga dapat dilakukan dengan memanfaatkan media flash cards atau kertu bergambar. Menurut Kasihani (2007: 109), "flashcards are teaching aids as picture paper which has 25x30. The pictures is made by hand, pictures or photo which is stick on the flashcard." (Flash card adalah media pembelajaran dalam bentuk kartu bergambar yang berukuran 25x30. Gambar-gambarnya dibuat dengan tangan, foto, atau memanfaatkan gambar/foto yang sudah ada ditempelkan pada lembaran-lembaran flashcard). Flashcard adalah kartu belajar yang efektif yang mempunyai dua sisi dengan salah satu sisi berisi gambar, teks, atau tanda simbol dan sisi lainnya berupa definisi, keterangan gambar, jawaban, atau uraian yang membantu mengingatkan atau mengarahkan siswa kepada sesuatu yang berhubungan dengan gambar yang ada pada kartu. Ukuran flashcards dapat disesuaikan dengan besar kecilnya kelas yang dihadapi. Flashcards merupakan media grafis yang praktis dan aplikatif. Maka, dapat disimpulkan bahwa flashcards mempunyai ciri-ciri sebagai berikut (1) Flashcards berupa kartu bergambar yang efektif, (2) Mempunyai dua sisi depan dan belakang, (3) Sisi depan berisi gambar atau tanda simbol, (4) Sisi belakang berisi definisi, keterangan gambar, jawaban, atau uraian, (5) Sederhana dan mudah dibuat.

Dalam pelaksanaan pengabdian masyarakat ini, pelaksana memilih dua Taman Kanak-Kanak di wilayah kecamatan Beji, Depok, yaitu Taman Kanak-Kanak Miftahul Jannah, yang berlokasi di jalan Pinang III, dan Taman Kanak-Kanak Al-Ihsan yang beralamat di jalan Margonda Raya gang Fatimah. TK Al-Ihsan adalah sebuah TK yang bernaung di bawah Yayasan Al-Ihsan. TK ini terdiri dari lima kelas yang dibagi menurut tingkatan umur murid, yaitu kelas A2 (3-4 tahun), kelas A1 (4-5 tahun), kelas B2 (5-6 tahun), dan kelas B1 (6-7 tahun). Menjadi pilihan bermitra dengan keluarga muslim di dalam menjalankan roda pendidikan, berwawasan luas dan akhlakul karimah adalah visi dari sekolah ini. Selain mempriotritaskan penanaman nilai-nilai agama dalam pembelajaran, TK ini juga memiliki beberapa program penunjang dan ekstrakulikuler, salah satunya pelajaran bahasa Inggris yang diberikan untuk setiap kelas, dari A2 sampai B1.

Observasi yang pelaksana lakukan di lapangan menunjukkan beberapa hal yang sebaiknya dilakukan untuk meningkatkan efektivitas pem-belajaran bahasa Inggris di TK Al-Ihsan. Pelajaran bahasa Inggris diberikan sekali dalam seminggu selama 30 menit untuk setiap kelas. Materi difokuskan pada materi kosakata seperti mengenal angka, warna, benda-benda, binatang, huruf, namanama hari dan bulan, konsep waktu, serta kegiatan-kegiatan sehari-hari yang disesuaikan dengan tema yang sedang dibahas pada minggu itu. Metode pembelajaran yang digunakan adalah metode klasikal yaitu guru mengajarkan kosakata dengan melafalkan, menuliskan, dan menjelaskan artinya secara 
berulang-ulang, kemudian murid meniru dan melafalkan kosakata tersebut juga secara berulang-ulang. Untuk melengkapi pembelajaran, murid-murid juga diberikan buku dan multimedia berupa video berbahasa Inggris.

Taman Kanak-Kanak kedua yang dipilih adalah TK Miftahul Jannah yang juga berlokasi di Kecamatan Beji Depok. Sama dengan TK Al-Ihsan, TK ini juga bernuansa Islami. TK ini didirikan sebagai bentuk kepedulian akan pendidikan usia dini, khususnya untuk masyarakat bergolongan ekonomi menengah ke bawah. Dari hasil pengamatan awal tim pelaksana, ada perbedaan antara TK Al-Ihsan dan TK Miftahul Jannah. Miftahul Jannah tidak memberikan pelajaran bahasa Inggris kepada murid-muridnya karena ketidaktersediaan tenaga pengajar. Bisa dikatakan, murid-murid Miftahul Jannah sama sekali belum mendapatkan pengalaman belajar bahasa Inggris secara formal. Hal inilah yang membuat tim pelaksana tertarik untuk memperkenalkan pentingnya mempelajari bahasa Inggris sejak usia dini di TK tersebut.

Metode pembelajaran dan ketersediaan media pembelajaran bahasa Inggris di TK Al-Ihsan yang sudah cukup baik, namun ada beberapa hal yang bisa dilakukan untuk meningkatkan keefektifan pembelajaran bahasa Inggris. Mengingat sedikitnya waktu yang dialokasikan untuk pelajaran ini, alangkah baiknya jika murid juga bisa mengulang dan menambah perbendaharaan kosakata mereka di rumah dengan belajar bersama wali murid. Pembelajaran yang rutin dan menyenangkan akan sangat efektif untuk membantu murid untuk menguasai kosakata. Rutinitas belajar tidak hanya dapat dilakukan oleh guru di sekolah tapi tentu saja oleh wali murid di rumah. Karena itu, wali murid perlu dibekali dengan pengetahuan tentang teknik pengajaran kosakata. Dengan mempertimbangkan hal-hal tersebut tim pelaksana memandang perlu untuk memberikan pelatihan kepada wali murid tentang teknik yang bisa digunakan untuk mempelajari kosakata di rumah. Untuk itu, kegiatan pengabdian kepada masyarakat ini bertujuan untuk memberikan pelatihan kepada wali murid tentang teknik pengajaran kosakata bahasa Inggris sehingga wali murid bisa menerapkannya di rumah bersama anakanak. Teknik yang dipilih adalah teknik dengan menggunakan realia dan flash cards. Keduanya dipilih karena dipandang mungkin untuk diterapkan di rumah dan juga untuk memberikan variasi dalam pengajaran kosakata. Selain itu, keduanya bisa saling mendukung satu sama lain.

\section{METODE PELAKSANAAN}

Pelatihan yang diberikan kepada guru dan wali murid dalam program pengabdian masyarakat ini bertujuan untuk memberikan pengetahuan dan keterampilan kepada guru dan wali murid tentang teknik pengajaran kosakata bahasa Inggris kepada anak. Diharapkan setelah mengikuti pelatihan ini peserta dapat menerapkannya di rumah bersama anak. Dalam pelaksanaan pelatihan ini, tim pelaksana mengadopsi konsep Three Period Lesson yang selama ini dipakai di sekolah-sekolah Montessori untuk mengembangkan penguasaan kosakata murid. Konsep ini pada awalnya dikembangkan oleh Edouard Seguin dalam Jackson, seorang dokter Perancis yang bekerja dengan anak berkebutuhan khusus di Perancis dan Amerika Serikat pada akhir abad ke19. Ia menemukan cara untuk meningkatkan kemampuan kognitif anakanak dan percaya pada pentingnya mengembangkan kemandirian dan kemerdekaan. Tulisan Seguin ini adalah 
inspirasi utama untuk Maria Montessori dan sumber dari banyak ide-ide praktis nya.

Seguin dalam Jackson (2011: 1416) membagi Three period lesson ke dalam tiga tahap sebagai berikut:

1. Naming Period (Introduction)

Pada periode ini wali murid bertindak sebagai pelaksana yang memperkenalkan kosakata kepada anak dengan cara menunjuk objek satu persatu sambil mengulang-ulang nama objek tersebut dengan pelafalan yang benar. Anak hanya menyimak, mendengar, dan memperhatikan saat wali murid mengenalkan objek-objek tersebut. Kalimat yang biasa digunakan pada tahap ini adalah "This is....".

2. Recognition and Association Period (Identification)

Tahap ini adalah yang terpanjang masa pelaksanaanya. Pada tahap ini anak perlu memiliki banyak pengalaman mendengar nama-nama benda. Anak akan menghubungkan kata dengan objek. Anak diinstruksikan untuk mengidentifikasi benda sesuai dengan nama yang disebutkan oleh wali murid. Kalimat yang biasanya digunakan di periode ini adalah "Show me...". Proses ini mungkin akan terus berlangsung selama beberapa hari atau minggu. Jika anak belum dapat mengidentifikasi benda/objek dengan benar, maka wali dan anak harus kembali ke periode 1 .

3. Recall Period (Cognition)

Di periode ini anak mengingat kembali apa yang telah diperolehnya di periode-periode sebelumnya. Biasanya kalimat yang digunakan di periode ini adalah "What is this?". Jika anak sudah dapat menunjukkan dan menyebutkan nama benda/objek dengan benar maka dia sudah sampai pada tahap kognisi. Namun, bila anak masih belum bisa menunjukkan dan menyebutkan dengan benar, maka itu adalah indikasi belum cukupnya latihan di periode sebelumnya. Jika hal ini terjadi, wali dan anak bisa kembali ke periode dua.

\section{HASIL DAN PEMBAHASAN}

Penguasaan kosakata yang baik dapat dicapai salah satunya dengan menggunakan metode dan teknik yang tepat dalam proses pembelajaran. Metode dan teknik konvensional memang cukup efektif untuk membantu anak untuk menguasai kosakata, namun terkadang metode dan teknik tersebut juga menimbulkan kebosanan pada anak karena kurang adanya variasi. Kebosanan tentu saja akan mempengaruhi motivasi anak dalam belajar. Karena itu dibutuhkan metode dan teknik yang lebih variatif sehingga anak berkesempatan untuk merasakan pengalaman baru yang lebih menyenangkan ketika belajar. Kesesuaian antara metode dan teknik pengajaran memiliki peran penting dalam mencapai suatu tujuan pengajaran yang diharapkan. Metode pengajaran bahasa bukanlah sebatas cara pengajaran, akan tetapi adalah suatu kesatuan yang utuh antara pemikiran dan pelaksanaannya yang mengedepankan ketepatan antara teknik dan prinsip pengajaran bahasa sehingga tujuan pengajaran dapat tercapai dengan baik.

Pembelajaran yang rutin dan menyenangkan akan sangat efektif untuk membantu murid untuk menguasai kosakata. Rutinitas belajar tidak hanya dapat dilakukan oleh guru di sekolah tapi tentu saja juga oleh wali murid di rumah. Karena itu, wali murid perlu dibekali dengan pengetahuan tentang teknik pengajaran kosakata. Dengan mempertimbangkan hal-hal tersebut tim pelaksana memandang perlu untuk 
memberikan pelatihan kepada wali murid tentang teknik yang bisa digunakan untuk mempelajari kosakata di rumah. Untuk itu, kegiatan pengabdian kepada masyarakat ini bertujuan untuk memberikan pelatihan kepada wali murid tentang teknik pengajaran kosakata bahasa Inggris sehingga wali murid bisa menerapkannya di rumah bersama anak-anak. Teknik yang dipiih adalah teknik dengan menggunakan media realia dan flash cards. Kedua teknik ini dipilih karena dipandang mungkin untuk diterapkan di rumah dan juga untuk memberikan variasi dalam pengajaran kosakata. Kedua teknik ini bisa saling mendukung satu sama lain. Tentu saja pelaksana mengharapkan, setelah mendapatkan pelatihan ini, wali murid dapat menerapkannya di rumah bersama anak-anak.

Dari uraian di atas terlihat bahwa sasaran utama dari pelaksanaan Abdimas ini adalah orang tua atau wali murid TK yang akan lebih banyak berinterksi dengan anak di luar jam sekolah. Oleh karena itu tim pelaksana berfokus pada peningkatan pengetahuan dan keterampilan orang tua untuk mengajarkan kosakata kepada anak-anak mereka di rumah. Dalam pelaksanaannya terntu pelaksana tetap melibatkan anak untuk mempraktekkan ilmu yang didapat oleh orang tua mereka.

Dalam pelaksanaanya, pengajaran kosakata dengan menggunakan media realia dan flash cards ini sangat efektif untuk meningkatkan minat belajar anak. Orang tua diperkenalkan terlebih dahulu tentang definisi kedua teknik. Teori diberikan guna menambah wawasan peserta tentang kedua media ini dilengkapi dengan contoh-contoh yang diberikan oleh tim pelaksana. Bagian yang paling menyenangkan tentu pada saat peserta harus mempraktekkan ilmu yang telah mereka dapat langsung kepada anak. Beberapa orang tua masih merasa canggung bahkan gugup saat praktek karena saat itu adalah kali pertama mereka mengajarkan Bahasa Inggris langsung kepada anak mereka dengan teknik yang baru mereka dapatkan. Namun sebagian besar peserta menampakkan perkembangan yang cukup signifikan yang tentu saja juga berpengaruh terhadap meningkatnya minat belajar dan penguasaan kosakata anak.

Pengajaran kosakata dengan teknik realia dan flashcards ini dilakukan dengan mengaplikasikan metode three period lesson yang terdiri dari periode naming, periode recognizing, dan periode recalling. Pada tahap pertama, Naming Period, tim pelaksana menjelaskan bahwa wali murid bertindak sebagai pelaksana yang memperkenalkan kosakata kepada anak dengan cara menunjuk objek satu persatu sambil mengulang-ulang nama objek tersebut dengan pelafalan yang benar. Wali murid bertindak sebagai model. Anak hanya menyimak, mendengar, dan memperhatikan saat wali murid mengenalkan objek-objek tersebut. Kalimat yang biasa digunakan pada tahap ini adalah "This is....". Pada tahap ini beberapa orang tua mengeluhkan kemampuan mereka yang sangat terbatas dalam menguasai kosakata. Tim pelaksana memberikan solusi untuk mengatasi hal tersebut. Bahwa pada intinya pada tahap ini baik wali murid dan anak-anak sedang sama-sama belajar. Hal yang paling utama adalah niat dan kemauan. Jika wali murid menunjukkan semangat dan optimisme yang tinggi, maka hal baik itu akan menular kepada anak. Anak akan bertambah semangat untuk belajar karena melihat orang tuanya juga bersemangat. Dengan motivasi dan latihan praktek yang tim pleaksana berikan, wali murid menunjukkan perkembangan kemauan dan kemampuan yang signifikan pada 
tahap ini. Mereka mulai berani untuk mengucapkan dengan benar, menjelaskan, dan berekspresi ketika mereka bertindak sebagai model bagi anak mereka masing-masing. Anak-anakpun terlihat antusias mengikuti tahap ini.

Tahap selanjutnya adalah recognition period. Wali murid bisa masuk ke tahap ini bila mereka menilai anak sudah cukup baik di tahap sebelumnya. Tim pelaksana menjelaskan bahwa pada tahap ini anak perlu memiliki banyak pengalaman mendengar nama-nama benda. Anak akan menghubungkan kata dengan objek. Anak diinstruksikan untuk mengidentifikasi benda sesuai dengan nama yang disebutkan oleh wali murid. Kalimat yang biasanya digunakan di periode ini adalah "Show me...". Proses ini mungkin akan terus berlangsung selama beberapa hari atau minggu. Jika anak belum dapat mengidentifikasi benda/objek dengan benar, maka wali dan anak harus kembali ke periode 1 . Kendala yang dihadapi pada tahap ini umumnya berhubungan dengan kemampuan anak untuk mengingat dan mengidentifikasi benda yang diminta oleh orang tuanya. Pada sisi orang tua sendiri, kendala lebih pada kesabaran orang tua untuk menunggu jawaban yang benar dari si anak. Ekspektasi mereka akan jawaban yang benar dari si anak kadang tidak terpenuhi dan itu membuat mereka sedikit kewalahan dan kehilangan kesabaran. Untuk mengatasi masalah ini, tim pelaksana kembali menekankan bahwa anak belajar sambal bermain. Suasana harus dibuat gembira sehingga anak tidak merasa terpaksa untuk mengikuti pelajaran. Butuh kesabaran yang lebih untuk mengajar anak-anak usia dini. Pada akhir sesi ini, terlihat kemajuan kemampuan orang tua dan kemajuan kemampuan anak mengingat benda-benda.
Tahapan terakhir adalah recall period. Di periode ini anak mengingat kembali apa yang telah diperolehnya di periode-periode sebelumnya. Biasanya kalimat yang digunakan di periode ini adalah "What is this?". Jadi pada tahap ini anak diminta untuk menunjukkan sekaligus menyebutkan nama benda dengan pelafalan yang benar. Jika anak sudah dapat menunjukkan dan menyebutkan nama benda/objek dengan benar maka dia sudah sampai pada tahap kognisi. Namun, bila anak masih belum bisa menunjukkan dan menyebutkan dengan benar, maka itu adalah indikasi belum cukupnya latihan di periode sebelumnya. Jika hal ini terjadi, wali dan anak bisa kembali ke periode dua. Kendala pada tahap ini adalah kesalahan pelafalan anak yang tidak teridentifikasi oleh orang tua karena seperti disebutkan sebelumnya, sebagian besar wali murid tidak memiliki kemampuan bahasa Inggris yang baik. Namun secara garis besar, orang tua mampu mempraktekkan setiap tahap penagajaran dan anak dapat dengan mudah mengenali dan mengingat kosa kata baru yang mereka terima.

Khusus untuk media flash cards tim pelaksana memperkenalkan dan mencontohkan beberapa permainan yang bisa dimainkan dengan anak untuk membantu mereka menguasai kosakata. Beberapa permaian itu adalah flash (permaian flash cards dengan membuka kartu secara cepat dan anak menebak kartu apa yang mereka lihat), slowlyslowly (kebalikan dari flash, permainan dengan membuka kartu dengan perlahan kemudian anak menebak kartu apa yang mereka lihat), stop (wali murid menyebutkan sebuah kata kemudian membuka kartu satu persatu sambil menunggu anak mengucapkan stop di kata yang dimaksud), dan magic eyes (permainan dendan menempelkan beberapa kartu di papan tulis kemudian menyebutkan kata satu persatu dengan 
irama tertentu. Satu persatu kartu dibuka namun anak tetap menyebutkan semua kata dengan irama yang sama). Sebenarnya ada banyak sekali permainan yang bisa dimainkan dengan menggunakan flash cards, namun ke empat permainan ini dipilih karena tim menilai keempatnya sangat mudah dan sederhana sehingga cocok dimainkan oleh anak usia 4-6 tahun dengan dipandu oleh orang tua mereka.

Pada setiap tahapan pelaksanaan tim pelaksana meminta wali murid untuk melakukan praktek langsung bersama anak mereka. Cara ini dilakukan agar anak juga mengetahui bahwa orang tua mereka sedang belajar Bahasa Inggris dan nantinya akan mengajarkan mereka di rumah. Pada saat permainan dengan flash cards masih banyak wali murud yang belum dapat mengeluarkan ekspresi yang dapat membantu anak untuk mengingat kosakata. Nasmun secara umum, semua peserta terlihat sangat antusias walaupun masih ada beberapa orang yang terlihat kaku dan gugup.

Pelatihan pengajaran kosakata dengan media realia dan flash cards ini diharapkan dapat memberikan hasil dan manfaat yang besar bagi peserta. Hasil (output) yang diwujudkan ke dalam luaran (output) pembelajaran agar dapat digunakan khalayak ramai, dalam hal ini secara khusus terhadap dunia pendidikan dan pengajaran. Adapun luaran yang dapat dihasilkan dari kegiatan pembelajaran ini antara lain berupa alat bantu ajar yaitu seperangkat flash cards agar dapat digunakan khalayak ramai. Flashcards dibuat sendiri oleh tim dengan mengambil bahan dari berbagai sumber dan kemudian mencetaknya menjadi kartu-kartu bergambar yang menarik.

Berikut adalah foto-foto kegiatan pelaksanaan pengabdian kepada masyarakat
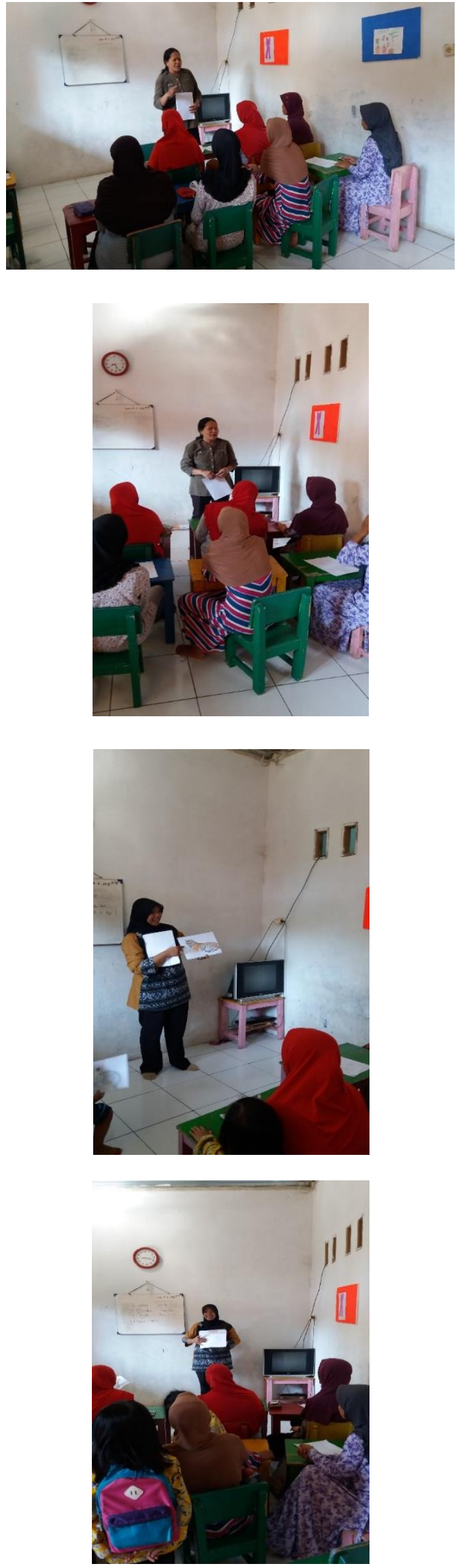

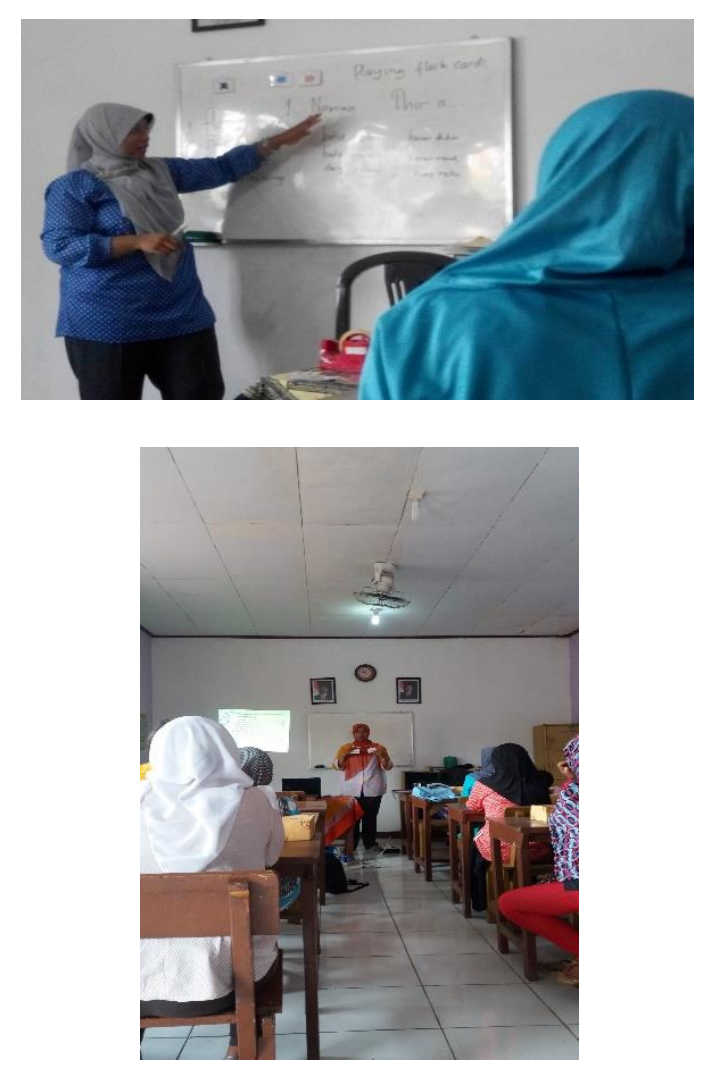

\section{SIMPULAN}

Dari hasil pelaksanaan kegiatan pengabdian kepada masyarakat ini, dapat ditarik beberapa kesimpulan sebagai berikut:

1. Penerapan pengajaran kosakata dengan media realia dan flashcards dengan menerapkan metode three period lesson dikatakan efektif dalam meningkatkan kemampuan penguasaan kosakata murid. Penerapan teknik dan metode ini memudahkan dan memberikan cara yang sistematis kepada wali murid untuk mengajarkan kosakata kepada anak mereka masing-masing.

2. Penerapan pengajaran kosakata dengan media realia dan flashcards dengan menerapkan metode three period lesson juga efektif untuk menumbuhkan minat belajar anak karena anak dimungkinkan untuk merasakan nuansa pembelajaran dan pengalaman baru yang lebih menyenangkan. Hal ini berampak positif terhadap peningkatan penguasaan kosakata anak.

\section{DAFTAR PUSTAKA}

Bryan, S. (1997). Virtual Realia: Program in Second Language Acquisition and Teaching. the InterNet TESL Journal III.

Fauziati, E. (2010). Teaching English as a Foreign Language. Surakarta: Era

Jackson,L.W.R (2011). The Montessori Method's Use of Seguin's Three Period Lesson and It's Impact on the Book Choices and Word Learning of Students Who Are Deaf or Hard of Hearing. Disertation. Columbia University.

Kasihani, S.(2007). English for Young Learners Melejitkan Potensi Anak Melalui English Class yang Fun, Asyik, dan Menarik. Jakarta : Bumi Aksara.

Larsen-Freeman, D. (2000). Techniques and Priinciples in Language Teaching. Second Edition. New York: Oxford University Press.

Nunan, D. (1999). Second Language Teaching and Learning. Boston: Heinle and Heinle. 